\title{
The Effect of Teaching Grammar through Consciousness Raising Tasks on High School English Learners' Grammatical Proficiency
}

\author{
Nahid Yarahmadzehi, PhD \\ Assistant Professor at English Department of Faculty of Management and Humanities, Chabahar Maritime University, Iran \\ venayarahmadi@gmail.com
}

\section{Alikaram Esfandiari Ghalaee \\ Seyyed Farzad Kalali Sani}

Doi:10.5901/mjss.2015.v6n3s1p401

Chabahar Maritime University, Iran esfandiariali77@gmail.com,\& farz1dk@gmail.com

\section{Abstract}

Despite the fact that teaching grammar is controversial in modern trends to methodology, grammar knowledge and its function is of great significance for all language skills. With the view that formal instruction is important for raising learners' consciousness of grammatical structures, this quasi experimental study is an attempt to investigate the impact of teaching grammar through indirect consciousness raising tasks on learners' grammatical knowledge versus conventional grammar approaches such as target grammar explanation through native language and pattern practice. To this end, sixty six male intermediate-level (determined through Nelson Language Proficiency test) students of four intact classes, two second-grade and two third-grade classes, at a public high school in Dashtestan, Bushehr, Iran, participated in the study. Two classes formed two experimental groups performing grammar consciousness raising tasks, and the other two classes formed two control groups receiving grammar lessons identical in content to the consciousness-raising tasks through traditional approaches. Considering first research question, Pre-test and post-test mean values of 8.05 and 25.05 [Sig. (2-tailed) = p-value $.000<0.05$ ] of the second grade experimental group as well as the third grade experimental group's pre-test and post-test mean values of 6.40 and 24.27 [Sig. (2-tailed) $=.000<0.05$ ] obtained through paired samples t-test indicated that consciousness raising tasks were effective enough to help subjects make significant progress in their grammatical ability. Regarding second research question, although the mean score of the second grade experimental group 25.05 was higher than the mean score of the control group 23.8 obtained through independent sample t-test, this difference was not significant. In the case of third grade experimental and control groups with the mean values of 24.27 and 21.14 on the post-test respectively [Sig. (2-tailed) $=p$-value $=0.013<0.05]$, CRT grammar instruction was more effective than traditional grammar instruction in the development of the third grade experimental group's grammatical ability.

Keywords: grammar teaching, explicit knowledge, implicit knowledge, consciousness-raising task, traditional approaches

\section{Introduction}

A glance at the last century of language-teaching practices reveals different opinions about the place of teaching grammar. Historically, language teaching methods have various positions regarding grammar teaching from zero grammar to total grammar. Proponents of natural methods rejected any explicit teaching of grammar. Therefore, implicit approach was common in the Direct Method, Audiolingual Method and Natural Approach. Through exposure to demonstrations, situations or examples, learners were expected to pick up the rules of grammar by inductive learning. On the other hand there are approaches such as Grammar-Translation and Cognitive-Code Learning that favor an explicit and deductive learning approach. Learners are presented with rules which they study and then practice.

Most Current views of grammar teaching focus on the importance of some form focused instruction such as noticing and consciousness-raising techniques. Based on some variables such as learners' age, proficiency level, educational background, learners' needs and goals as well as the context, teachers can choose among various options of teaching grammar. Occupying a midway point between zero grammar and total grammar is the approach called consciousness-raising which is the focus of this research. This study is related to the previous studies by Schmidt $(1990,1993,1995)$, Ellis $(1994,2002,2003)$ and Fotos $(1994)$ who have all investigated the merits of promoting learners' consciousness of grammatical form. 


\section{Review of the Related Literature}

\subsection{Arguments in Favor of Grammar Instruction}

Nassaji and Fotos (2004) stated that "Current research clearly indicates that grammar feedback is necessary in order for language learners to attain high levels of proficiency in the target language" (p.137). Ellis $(1993,2003)$ maintained that formal grammar instruction is effective in developing explicit knowledge of grammatical features. According to Ellis, explicit knowledge gained thorough grammar instruction helps learners in three ways. First, it helps them monitor their utterances before and after they are produced. Second, it helps learners notice certain features in the input. Third, explicit knowledge helps learners notice the gaps in their output: "If learners know about a particular feature they are better equipped to detect the difference between what they themselves are saying and how the feature is used in the input they are exposed to" (Ellis, 1993,p. 149). Therefore, becoming aware of this gap is likely to result in the production of more accurate utterances in their subsequent performance.

There are many reasons and arguments for the reevaluation of grammar as a necessary component of language instruction. First, the 1980s hypothesis that language can be learned without some degree of consciousness has been found theoretically problematic (Nassaji \& Fotos, 2004). Schmidt $(1990,1993)$ suggested that conscious attention to form, or what he called "noticing," is a necessary condition for language learning. A second reason for the renewed interest in L2 grammar instruction is related to the matter that L2 learners pass through developmental sequences (Nassaji \& Fotos, 2004). It is believed that items can only be learned when they are a little beyond a learner's current processing capacity, and it is what has been known as "teachability hypothesis" (Bardovi-Harling \& Comajoan, 2008, p. 393). The third reason which has led to the reconsideration of the importance of grammar is a large body of research pointing to the inadequacies of teaching approaches which primarily focus on meaning with no focus on grammar (Ansarin, \& Arasteh , 2012; Celce-Murcia, Dörnyei \& Thurrell ,1997). The last reason which puts emphasis on significance role of grammar teaching in the L2 classroom is due to the numerous studies and arguments which have proved the positive results of grammar instruction especially on the achievement of L2 accuracy (Ansarin \& Arasteh 2012; Baleghizadeh, 2012; Colina \& Mayo, 2007; Ellis,1992,1993,1994, 2006; Fotos, 1993,1994; Fotos, \& Ellis,1991; Jalali, 2012; Kojima, 2004; Mohamed, 2004; Naeini, 2008; Nassaji \& Fotos, 2004; Nitta \& Gardner, 2005 ; Osuka \& Yamamoto, 2005; Rachmawati, 2011; Sarhady, 2011; Shokouhi, 2009). All the preceding arguments seem convincing enough to claim that grammar teaching should be an inseparable part of ESL/EFL classes.

\subsection{Some Issues in Teaching Grammar}

\subsubsection{Explicit and Implicit L2 knowledge}

It is stated that learners have two types of knowledge, explicit knowledge and implicit knowledge, to gain proficiency in a target language and their distinction is related to cognitive psychology. Implicit knowledge is entirely tacit and unconscious, whereas explicit knowledge is conscious. Implicit knowledge is procedural and it is not available for selfreport while explicit knowledge is declarative and people can express such knowledge about the language in words, although they may not have the proper verbal repertoire to phrase their knowledge accurately.

It is worth knowing that "L2 performance utilizes a combination of implicit and explicit knowledge" (Ellis, 2009a, p. 15). As Bialystok (cited in Ellis, 2009a, p. 15) has pointed out, learners use both systems to construct messages. As mentioned earlier the relationship between implicit and explicit knowledge is disputatious. The questions here are to what extent implicit and explicit learning are related and whether explicit knowledge changes into implicit knowledge. These issues concern what has become known as the interface hypothesis (Ellis, 2006). Regarding this hypothesis, three positions can be identified: (a) the noninterface position, (b) the strong interface position and (c) the weak interface position (Hulstijn, 2005). Each of these will be considered respectively. The noninterface position deals with the matter that the explicit and implicit knowledge systems are completely separate from each other, and it is strongly associated with Krashen(1981) and his theory of second language acquisition ( Tavakoli, 2012). The strong interface position entails a strong relation between explicit and implicit knowledge and they are seen as the extremes of one continuum (Dekeyser, 2009). This means that linguistic knowledge changes in the course of acquisition in such a way that it becomes more available in communicative settings.

The weak interface position claims that (Dekeyser, 2009) implicit and explicit knowledge are two separately coexisting knowledge systems and explicit knowledge can change into implicit knowledge if the learner is ready to acquire the targeted feature. The weak interface position also states that explicit knowledge can positively affect implicit 
learning processes, but in such cases, the effects of instruction will be delayed rather than immediate (Dekeyser, 2009).

The three positions support different approaches to language teaching. Zero grammar approach which gives priority to meaning-centered approaches such as task-based teaching is supported by non-interface position. PPP approach - presentation, practice and production of a grammatical structure - is advocated by strong interface position as well. The weak interface position justifies the use of C-R tasks by stressing the importance of learners' actively discovering their own explicit grammar rules from data they are provided with (Ellis, 1993, 2005a, 2006).

\subsubsection{Inductive or Deductive Grammar instruction}

Inductive approach to grammar instruction is defined as the processes in which learners' attention is focused on consciously analyzing a number of examples given so as to discover the underlying grammatical rule governing the use of a particular structure in those examples. Contrasting to that, deductive approach to grammar instruction is defined as learners' receiving teachers' explanation of the concerned grammatical rule first, which is then followed by their analyzing and practicing the application of such a rule in the examples or exercises provided. It is worth mentioning that both are active cognitive processes. Deductive approach, therefore, relates to rule driven learning while inductive approach relates to rule discovery learning.

\subsection{Traditional Grammar Teaching and PPP Approach and Their Inadequacies}

Traditional ways of teaching grammar mostly deal with explicit, deductive and linear rule instruction followed by exercises including translation into and out of the mother tongue. In 1950s under the influence of the Audio-lingual Method, grammar was taught through the application of different activities consisting of mechanical pattern practices and drills such as repetition, replacement and substitution drills. Moreover, Grammar has traditionally been taught through production practice in which learners try to use grammatical structure in controlled and free exercises. Therefore, in traditional grammar lessons, teachers teach grammatical rules in isolation, and students have few opportunities to use them in real communication. The traditional grammar teaching following the PPP (Presentation, Practice and Production) sequence of the kind found in the Situational Language Teaching (SLT) deals with the presentation of a grammatical structure first, followed by controlled exercises and, finally, the provision of opportunities to produce it freely (Richards \& Rodgers, 2001).

Approaches to grammar instruction that focus on teaching grammar as a set of rules and structures have been criticized due to inadequacy in meeting $L 2$ learners' communicative needs. Moreover, in recent years, many researchers have questioned the assumptions underlying PPP model (Ellis, 2003; Richards \& Rodgers, 2001). It is stated that learners are not able to use what they have learned through this model (PPP) in a later lesson and outside the classroom or they use them incorrectly (Willis, 1996).

It has been pointed out that asking learners to produce grammatical structures which are difficult for them and then correcting their mistakes may increase their anxiety and result in a psychoaffective block to learning anything (Krashen, 1982). It has been pointed out that students easily forget the target structure they have learned through the PPP approach; since the students do not notice the target structure which is first presented by a teacher, practice and production tend to be mechanical without rule internalization (Osuka, \& Yamamoto, 2005).

Besides, the PPP procedure has been criticized because of being entirely teacher-centered and too restrictive in terms of the learner's experience of the TL (Willis 1996).

\subsection{Consciousness Raising Task as a New Approach to Grammar Teaching}

Grammar teaching has been subject to as many changes as any other aspect of language. It seems that the emphasis has moved from the teachers' task in teaching grammar to the learner's task in learning it and putting it into use, shifting the debate from what grammar is to how it can be taught to help students achieve this goal. While the inadequacies of a traditional focus on language structure alone are well documented (Richards \& Rodgers, 2001), the drawbacks of a strictly communicative approach have also been noted. Therefore, it is believed that learners need to pay attention to both meaning and form when learning a target language.

In conformity with the idea of helping learners improve their grammatical accuracy, Rodríguez (2009) concluded that "instructors should embed explicit focus on form within the context of meaningful learning activities and tasks that give learners ample opportunities for practice" (p. 4). Achieving this goal, Consciousness-Raising Task (CRT) as a kind of form-focused tasks has been mentioned by Ellis (2003). Ellis has pointed out that, consciousness-raising tasks are 
designed so that students can induce and formulate some grammatical rules from the presented sentences, through interacting and negotiating in small groups. Fotos $(1993,1994)$ found that this type of task provided opportunities for communication and promoted noticing.

The idea of realizing C-R in the form of communicative tasks was proposed by Ellis (1992), and the idea has subsequently been discussed quite extensively by Rod Ellis and Sandra Fotos (e.g. Ellis ,1994, 1997a, 2003; Fotos, 1994; Fotos \& Ellis, 1991; Nassaji \& Fotos, 2004). It is possible to integrate the teaching of grammar with opportunities for communication, exchange of information in grammar tasks. Fotos and Ellis (1991) recommended that a kind of a taskbased approach to grammar instruction called consciousness raising task (CRT) should be used to provide learners with grammar problems to solve. Fotos and Ellis also pointed out that CRT has an L2 grammar problem as the task content. It is believed that as the learners solve the grammar problem, not only do they put emphasis on the form of the grammar structure, but also they are involved in meaning-focused activities and their grammatical knowledge is developed while they are engaged in communication (Fotos \& Ellis, 1991). Ellis (1997) has defined grammar consciousness-raising tasks as:

a pedagogic activity where the learners are provided with L2 data in some form and required to perform some operation on or with it, the purpose of which is to arrive at an explicit understanding of some linguistic properties of the target language. ( cited in Nitta \& Gardner, 2005, p.3)

According to Ellis (2005b), consciousness-raising task is "a task that engages learners in thinking and communicating about language (often grammar). Thus, a language point becomes the topic that is talked about" (p. 47). Bankier (2010) argued that since giving importance to an extensive use of authentic communication has provided learners with good communication skills, but with limited grammatical accuracy, it is necessary for the teachers to find ways to develop both leaners' grammatical accuracy and communicative ability at the same time, without sacrificing one or the other. Consciousness raising is likely to do this end. Bankier (2010) continued that consciousness-raising activities provide learners with the enjoyable moments of learning a language through discovery learning. In a similar vein, Ellis (2003) stated that the content of such tasks is the grammatical structure itself which students are supposed to derive through interaction. The use of CRT is justified through discovery learning mode, problem-solving strategies, skill building theories; noticing hypothesis of Schmidt, theory of how input becomes intake, negative evidence and the weak interface position between explicit and implicit knowledge.

Ellis (1992, 2003) also argued that all CR activities share a number of key characteristics which include: preselecting and isolating a specific linguistic feature for focused attention; providing learners with data illustrating the use of this feature and, in some cases, also an explicit rule describing and explaining its form or use, the target structure can be underlined, color-coded, boldfaced or italicized; encouraging learners to invest intellectual effort in understanding the target structure; providing learners with clarification in the form of further data and description or explanation for learners' misunderstanding of the grammatical structure and finally optionally instructing learners to verbalize a rule underlying the use of the form. As pointed out earlier, because of several important differences, grammatical consciousness raising can be considered simply as opposed to Practice.

Willis, D. and Willis, J. (1996) also offered descriptions of the various options that are available for learners to operate on the samples of language in CR tasks: identification (e.g. underlining the target form); judgment (e.g. deciding whether the data are correct or appropriate); completion (e.g. filling in blanks in a passage with instances of a particular structure); modification or reconstruction/deconstruction (e.g. reordering or rewriting part of a text); sorting or classifying (e.g. assigning the forms present in the data to different categories); matching (e.g. combining two sets of data according to some stated principle); rule provision or hypothesis building (e.g. arriving at a verbal or non-verbal generalization).

\subsection{Research Questions}

This study aimed to examine the relative effectiveness of Consciousness Raising Tasks on high school intermediate learners' grammatical proficiency in Iran; hence, the two following research questions were addressed:

Q1. Does teaching grammar through Consciousness Raising Tasks have any significant role in developing the grammatical proficiency of high school learners?

Q2. Are there any significant differences between teaching grammar through Consciousness Raising Tasks and teaching grammar through traditional approaches like Practice and mother tongue explanation?

Thus, this study focused on the following hypotheses:

H01. Teaching grammar through Consciousness Raising Task has no significant role in developing grammatical proficiency of high school learners.

H02. There is no significant difference between teaching grammars through Consciousness Raising Task and 
teaching grammar through traditional approaches like Practice and mother tongue explanation.

\section{Methodology}

\subsection{Participants}

Sixty six male intermediate-level students being members of four intact classes at a public high school in Dashtestan, Bushehr, Iran, participated in the study. All the participants were at intermediate level and they were nearly at the same language proficiency level, which was determined through Nelson Language Proficiency test written by Flower \& Coe ( 1976). Foreign language learners participating in this study were all native speakers of Farsi ranged somewhere between 16 and 17 years old. Two second-grade classes and two third-grade classes of high school were selected for the experiment. One group in every pair was experimental and the other one was control group. Regarding this matter, 20 second-grade and 22 third-grade students comprised the pair of experimental groups and 10 second-grade and 14 thirdgrade students comprised the pair of control groups. The students falling between two standard deviations above and below the mean were included in the study as homogenous and no one was excluded.

\subsection{Design}

The present study dealt with quantitative research questions and the null or non-directional hypotheses. As it was an experimental research conducted in a classroom setting, it had the form of quasi-experiments, where there is no random assignment of subjects to groups. The following figure shows the design of the study clearly:

Table 1. Box Design of the Study

\begin{tabular}{|ccccc|}
\hline Groups & Grade & Pre-test & Treatment & Post-test \\
\hline G1 & Grade 2 of high school & O1 & X1 & O1 \\
G2 & Grade 2 of high school & O1 & - & O1 \\
G3 & Grade 3 of high school & O2 & X1 & O2 \\
G4 & Grade 3 of high school & O2 & - & O2 \\
\hline
\end{tabular}

As it is clear from the table, by applying two intact second grade high school classes and two intact third grade high school classes, two as experimental groups (G1, G3), the others were control/comparison groups (G2, G4), the researcher investigated the study questions by Pre-tests (O1 and $\mathrm{O} 2)$ and Post- tests ( $\mathrm{O} 1$ and $\mathrm{O} 2)$

\subsection{Materials and Instruments}

To explore the answer to the research questions the researcher applied the following instruments and instructional materials:

Before the research began, four classes took The Nelson $200 \mathrm{C}$ test including 50 multiple-choice items (Fowler \& Coe, 1976) to investigate whether there were significant differences in learners' English proficiency as well as their levels. The results of one-way ANOVA showed no significant differences between the groups prior to the treatment.

Before the treatment a standardized grammar test(from Cambridge Exam English.Com) was administered as a pretest to both groups in grade two and another one was administered as a pretest to both groups in grade three to further ensure learners' homogeneity regarding their knowledge of grammatical structures in every grade. Every test consisted of 20 multiple choice items and 10 gap-fill items constructed on the basis of the grammar points of students' text book. The 30 -item pretests were used also as the posttests.

The third instrument used in this study was inductive grammar consciousness-raising tasks (see appendix A) that were adapted from Alexander (1990) and Nettle \& Hopkins (2003). These tasks met the main criteria established by Ellis $(1992,2003)$ and Willis, D. \& Willis, J. (1996).

Another source used for both the control and experimental groups was some grammatical points of second and third grade high school books. Second grade high school grammatical points chosen for the study were as follow: conditional sentence (type 1), conditional sentence (type 2), and the article "the", relative pronouns, verb+ to + verb, preposition of time and reflexive pronouns. Third grade high school grammatical points utilized in this study included: the gerund, verb + object + infinitive, the order of adjectives, linking verbs, present and past participle used as adjective and 
the passives.

\subsection{Instruction for the Experimental Groups}

In experimental groups, the teacher assigned the students to some groups and made sure that one learner in each group would be more proficient than the other members to help the less proficient ones to understand and discover the rules more successfully. Each member of the group received a copy of the task sheet. Instead of giving explicit explanation about the target structures, the researchers employed a sequence of C-R tasks to make the learners discover how the aimed grammatical structures work. Learners were provided with explanations and clarifications they needed before, and during the task completion, and they were given enough time to complete the tasks. Teacher would also help learners in understanding the instructions. During the process, the teacher moved around the classroom, checked and helped the learners think of more challenging exercises. The consciousness-raising tasks were performed in both first language (L1) and target language (L2). Learners first processed the text for meaning. There was a reading activity in which the learners were to read a text illustrating the use of the grammar item and to interact with it in comprehending and grasping its meaning in the format of a comprehension exercise.

Then the teacher started a gradual shift from meaning to form. According to Willis, D. and Willis, J.'s (1996) taxonomy of CRTs, this would fit into the category of Identify/Consolidate; students were asked to read the text and underline all the instances of the aimed grammatical structure. In accordance with Ellis' (1992) taxonomy of CRT, in some tasks the learners were required to notice the boldfaced, underlined and colored instances of grammatical points. Next, in conformity with Ellis $(1992,2003)$ and Willis and Willis (1996), learners were encouraged and helped to determine grammar rules from evidence presented and arrive at an explicit understanding of the rule. This provided a basis for an error identification task, where they could check if they had understood the rule clearly. In this way, learners were asked to use their explicit knowledge of new grammatical structure to identify and correct errors of de-contextualized sentences. To raise their motivation, they were engaged in a sort of competition in which each group received a credit for finishing the task earlier. Finally, there was an opportunity for the learners to try to use the correct grammatical structure in their own sentences with the aid of some clues provided. The aim of this task was to encourage learners to experiment with the target structure, not its mastery.

\section{Results}

\subsection{Performance of the Subjects on General Proficiency Test}

Before the treatment, in order to see whether the subjects enjoyed the same level of English general proficiency, a Nelson English Language Test was administered to four groups. One Way ANOVA was run to compare the mean scores of four groups in order to make sure that the groups did not differ significantly before the treatment. Results from the OneWay ANOVA test revealed that there was not a significant difference at the $p<.05$ level among the four.

Table 2. Descriptive Statistics of All Subjects on Nelson General Proficiency Test

\begin{tabular}{|ccccccc|}
\hline \multirow{2}{*}{ performance } & \multirow{2}{*}{ N } & Mean & \multicolumn{2}{c}{$95 \%$ Confidence Interval for Mean } & Minimum & Maximum \\
\cline { 4 - 6 } & & & Lower Bound & Upper Bound & & \\
\hline experimental g2 & 20 & 29.70 & 27.61 & 31.78 & 24.00 & 38.00 \\
experimental g3 & 22 & 30.13 & 28.66 & 31.60 & 24.00 & 38.00 \\
control g2 & 10 & 30.10 & 24.54 & 35.65 & 20.00 & 43.00 \\
control g3 & 14 & 29.71 & 28.31 & 31.11 & 26.00 & 34.00 \\
Total & 66 & 29.90 & 28.83 & 30.97 & 20.00 & 43.00 \\
\hline
\end{tabular}

Although the performances of groups, regarding the mean score, are different, this difference is not statistically significant. Now, we can conclude that the four classes had equal language proficiency level.

Table 3. One-way ANOVA Test Results for the performance of Groups on Nelson general Proficiency Test

\begin{tabular}{|cccccc|}
\hline performance & Sum of Squares & df & Mean Square & F & Sig. \\
\hline Between Groups & 2.90 & 3 & .96 & .049 & .98 \\
Within Groups & 1226.54 & 62 & 19.78 & \\
Total & 1229.45 & 65 & & \\
\hline & & & \\
$c$ & 406 & & \\
\hline
\end{tabular}


Table (3) shows that there is no statistically significant difference among groups since Sig. value is .986 which is greater than .05 .

\subsection{Performance of Two Second Grade Classes on the Pre-test}

Table 4. Descriptive Statistics of Groups' Performances

\begin{tabular}{|cccccc|}
\hline & role & N & Mean & Std. Deviation & Std. Error Mean \\
\hline \multirow{2}{*}{ performance } & experimental g2 & 20 & 8.05 & 1.93 & .43 \\
& control g2 & 10 & 8.80 & 2.85 & .90 \\
\hline
\end{tabular}

Regarding what is displayed in this table; subjects were at the same level of the language proficiency regarding the targeted grammatical points.

Table 5. Independent-Samples T-test for the Performance of Two Second Grade Classes on the Pre-test

\begin{tabular}{|c|c|c|c|c|c|c|c|c|c|}
\hline & \multicolumn{2}{|c|}{$\begin{array}{l}\text { Levene's Test for } \\
\text { Equality of Variances }\end{array}$} & \multicolumn{7}{|c|}{ t-test for Equality of Means } \\
\hline & \multirow[t]{2}{*}{$\mathrm{F}$} & \multirow[t]{2}{*}{ Sig. } & \multirow[t]{2}{*}{$\mathrm{t}$} & \multirow[t]{2}{*}{$\mathrm{df}$} & \multirow{2}{*}{$\begin{array}{l}\text { Sig. }(2- \\
\text { tailed) }\end{array}$} & \multirow{2}{*}{$\begin{array}{c}\text { Mean } \\
\text { Difference }\end{array}$} & \multirow{2}{*}{$\begin{array}{l}\text { Std. Error } \\
\text { Difference }\end{array}$} & \multicolumn{2}{|c|}{$\begin{array}{c}\text { 95\% Confidence Interval } \\
\text { of the Difference }\end{array}$} \\
\hline & & & & & & & & Lower & Upper \\
\hline $\begin{array}{c}\text { Equal variances } \\
\text { assumed Performance }\end{array}$ & 3.21 & .08 & -.85 & 28 & .40 & -.75 & .87 & -2.55 & 1.05 \\
\hline $\begin{array}{l}\text { Equal variances not } \\
\text { assumed }\end{array}$ & & & -.74 & 13.25 & .46 & -.75 & 1.00 & -2.91 & 1.41 \\
\hline
\end{tabular}

Table 5 illustrates the $p$ value of the comparison of means is .40>.05, it was concluded that these two groups were homogenous in terms of their grammatical ability, so they could participate in the experiment.

\subsection{Performance of Two Third Grade Classes on the Pre-test}

Table 6. Descriptive Statistics of Groups' Performances

\begin{tabular}{|cccccc|}
\hline & role & N & Mean & Std. Deviation & Std. Error Mean \\
\hline \multirow{2}{*}{ performance } & experimental g3 & 22 & 6.40 & 1.76 & .37 \\
& control g3 & 14 & 6.21 & 1.76 & .47 \\
\hline
\end{tabular}

Regarding what is displayed in this table; subjects were at the same level of the language proficiency regarding the targeted grammatical points.

Table 7. Independent-Samples T-test for the Performance of Two third Grade Classes on the Pre-test

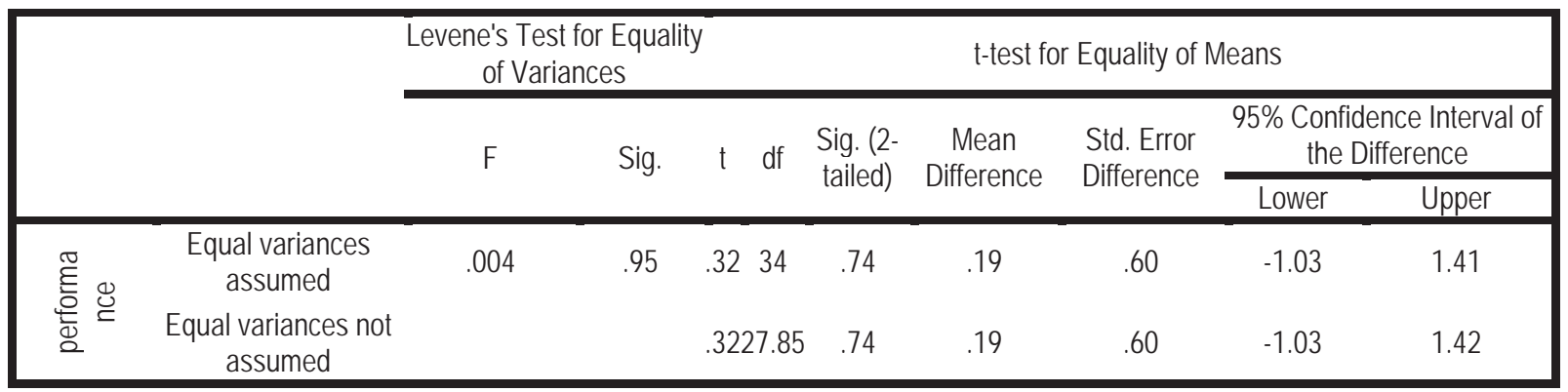

Table 7 illustrates the $p$ value of the comparison of means is $.74>.05$, it was concluded that these two groups were homogenous in terms of their grammatical ability. 


\subsection{Data Analysis for Research Question One}

Q1. Does teaching grammar through Consciousness Raising Tasks have any significant role on developing the grammatical proficiency of high school learners?

\subsubsection{Performance of the Second Grade Experimental Group on the Pre-test and Post-test}

Table 8. Paired Samples Statistics for the Second Grade Experimental Group

\begin{tabular}{|lccccc|}
\hline & & Mean & N & Std. Deviation & Std. Error Mean \\
\hline \multirow{2}{*}{ Pair 1 } & Pretest & 8.05 & 20 & 1.93 & .43 \\
& Posttest & 25.05 & 20 & 3.89 & .87 \\
\hline
\end{tabular}

The comparison of the pre-test and post-test of the second grade treatment group revealed a remarkable achievement in the grammatical proficiency mean scores of the participants.

Table 9. Paired-Samples T Test for the Performance of the Second Grade Experimental Group on the Pre \& Posttests

\begin{tabular}{|c|c|c|c|c|c|c|c|c|}
\hline & \multicolumn{5}{|c|}{ Paired Differences } & & \multirow{3}{*}{$\begin{array}{l}\text { Sig. (2- } \\
\text { tailed) }\end{array}$} \\
\hline & & \multirow[t]{2}{*}{ Mean } & \multirow[t]{2}{*}{ Std. Deviation } & \multirow[t]{2}{*}{ Std. Error Mean } & \multicolumn{2}{|c|}{$\begin{array}{l}\text { 95\% Confidence Interval of the } \\
\text { Difference }\end{array}$} & \multirow[t]{2}{*}{$t d f$} & \\
\hline & & & & & Lower & Upper & & \\
\hline Pair 1 & Pretest - Posttest & -17.00 & 2.55 & .57 & -18.19 & $-15.80-29.76$ & 19 & .00 \\
\hline
\end{tabular}

As it is depicted in Table 9, $p$ value is zero which means that there has been a significant progress in subjects' performances through implementing CRT grammar instruction.

\subsubsection{Performance of the Third Grade Experimental Group on the Pre-test and Post-test}

Table 10. Paired Samples Statistics for the third Grade Experimental Group

\begin{tabular}{|lccccc|}
\hline & & Mean & $\mathrm{N}$ & Std. Deviation & Std. Error Mean \\
\hline \multirow{2}{*}{ Pair 1 } & Pretest & 6.40 & 22 & 1.76 & .37 \\
& Posttest & 24.27 & 22 & 3.66 & .78 \\
\hline
\end{tabular}

The comparison of the pre- and post-tests of the third grade treatment group revealed a remarkable achievement in the grammatical proficiency mean scores of the participants.

Table 11. Paired-Samples T-test for the Performance of the Third Grade Experimental Group on the Pre-test and Posttest

\begin{tabular}{|c|c|c|c|c|c|c|c|}
\hline & & & Paired D & bifferences & & & \\
\hline & & & & 95\% Confiden & the Difference & $\mathrm{t}$ & f Sig. (2-tailed) \\
\hline & IVIean & sta. Devialion & sta. Error vied & Lower & Upper & & \\
\hline Pair 1 Pretest - Posttes & -17.86 & 2.37 & .50 & -18.91 & -16.81 & -35.2521 & .00 \\
\hline
\end{tabular}

As it is depicted in Table 11, $p$ value is zero which means that there has been a significant progress in subjects' performances through implementing CRT grammar instruction.

Therefore, consciousness raising tasks developed for the second and the third grade experimental groups were effective enough to help subjects make significant progress in their grammatical proficiency. 


\subsection{Data Analysis for Research Question Two}

Q2. Are there any significant differences between teaching grammar through Consciousness Raising Tasks and teaching grammar through traditional approaches like Practice and mother tongue explanation?

\subsubsection{Performance of the Second Grade Experimental and Control Groups on the Post-test}

Table 12. Group Statistics

\begin{tabular}{|c|c|c|c|c|c|}
\hline scores & $\begin{array}{c}\text { groups } \\
\text { Experimental } \\
\text { Control }\end{array}$ & $\begin{array}{l}\mathrm{N} \\
20 \\
10\end{array}$ & $\begin{array}{l}\text { Mean } \\
25.05 \\
23.80\end{array}$ & $\begin{array}{c}\text { Std. Deviation } \\
3.89 \\
4.49\end{array}$ & $\begin{array}{c}\text { Std. Error Mean } \\
.87 \\
1.42\end{array}$ \\
\hline
\end{tabular}

As indicated in table 12, the subjects' mean scores of the experimental and control groups on post-test were (25.05) and (23.80) respectively.

Table 13. Independent-Samples T-test for the Performance of the Second Grade Experimental and Control Group on the Post-test

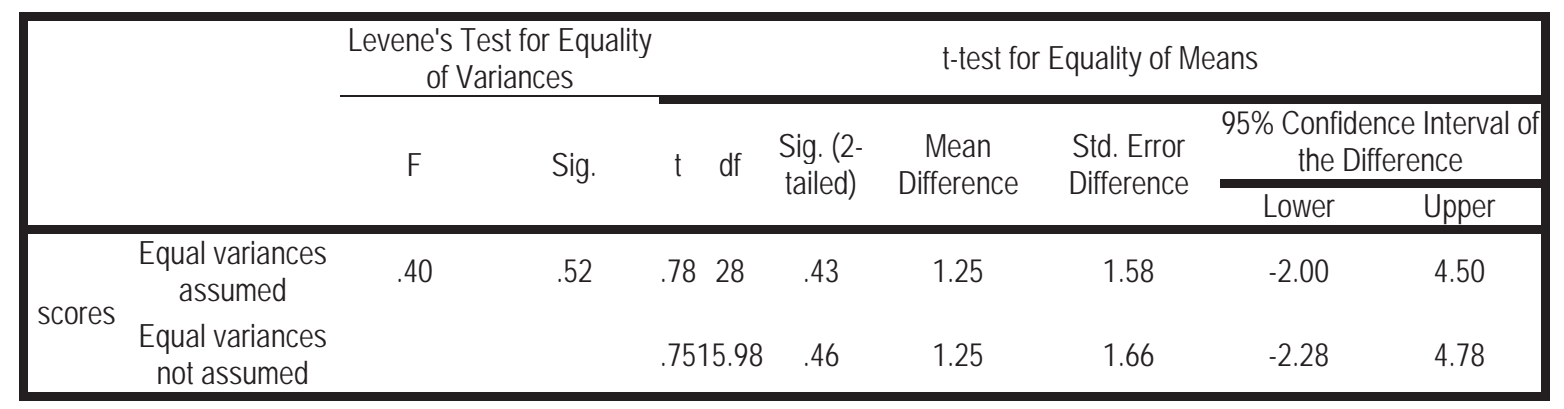

After the treatment, although the mean score of the second grade experimental group (25.05) was higher than the mean score of the control group (23.8), this difference was not significant. According to the above mentioned results (0.43 > 0.05), regarding second grade high school it was concluded that CRT grammar instruction was not more effective than traditional grammar instruction like Practice and mother tongue explanation in the development of the second grade subjects' grammatical knowledge.

\subsubsection{Performance of the Third Grade Experimental and Control groups on the Post-test}

Table 14. Group Statistics

\begin{tabular}{|cccccc|}
\hline & Groups & N & Mean & Std. Deviation & Std. Error Mean \\
\hline \multirow{2}{*}{ scores } & Experimental & 22 & 24.27 & 3.66 & .78 \\
& control & 14 & 21.14 & 3.20 & .85 \\
\hline
\end{tabular}

As indicated in this table, the subjects' mean scores of the experimental and control groups on post-test were (24.27) and (21.14) respectively.

Table 15. Independent-Samples T Test for the Performance of the Third Grade Experimental and Control group on the Post-test

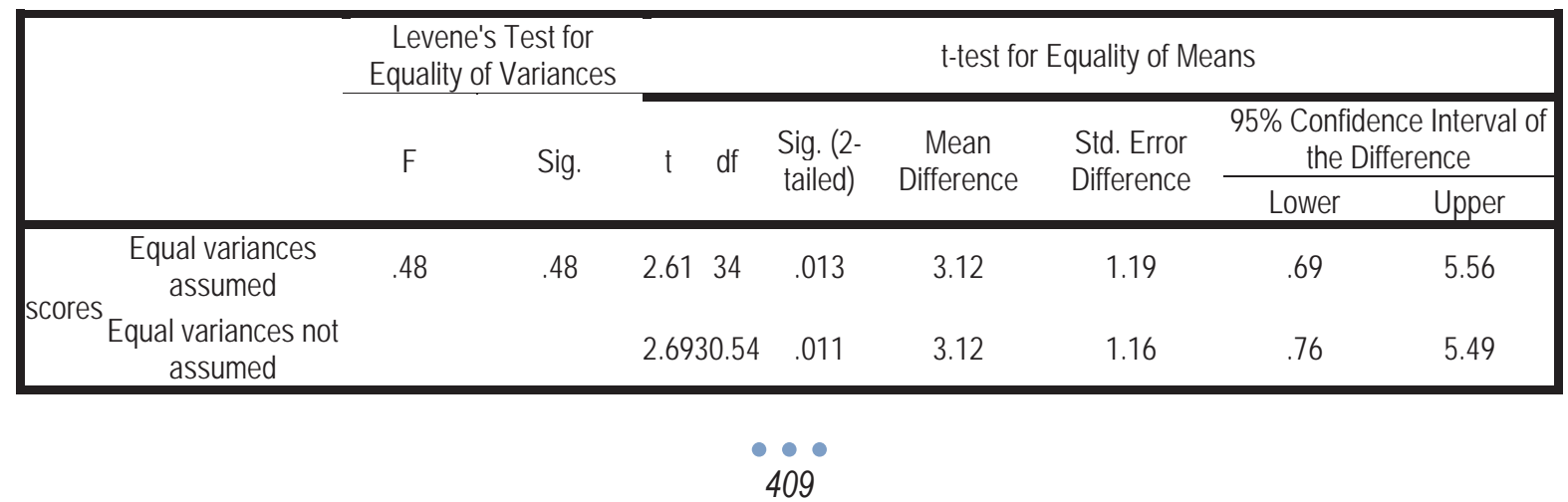


As it is depicted in Table 15, $p$ value of the mean is .01 which means that the performance of the third grade experimental group significantly differed from that of the control group. Consequently, it was concluded that that CRT grammar instruction was more effective than traditional grammar instruction in the development of the third grade subjects' grammatical ability.

\section{Discussion}

Regarding the first research question, comparison of the pre- and post-tests revealed a remarkable achievement in the grammatical proficiency mean scores of the participants. The participants within second grade experimental group significantly improved their knowledge of the target structures from the mean score of 8.05 on the pre-test to 25.05 on the post-test and the participants within third grade experimental group significantly improved their knowledge of the target structures from the mean score of 6.40 on the pre-test to 24.27 on the posttest. Since P value was lower than 0.05 , so the null hypothesis for the first research question is rejected. Considering this research question, it is possible to claim that consciousness raising tasks do have significant effect on learners' grammatical knowledge. The data generated in this study also suggest that implementing consciousness raising tasks at the intermediate level of English language instruction can help EFL learners improve their grammar tests performance.

In accordance with Fotos (1994), the results of the present study also showed that learners exposure to grammar through these tasks and formal instruction tend to consolidate their accuracy.

Regarding the second research question, the data obtained from posttests did not prove that there was significant difference between the experimental and control groups in grade two at the end of the experiment while there was significant difference between the third grade experimental and control groups. Regarding the mean scores, The second grade experimental group performance, with a mean equal to 25.05 , differed from the second grade control group on the post-test whose mean was 23.8 while the third grade experimental group, with a mean equal to 24.27 , outperformed the third grade control group on the post-test whose mean was 21.14 This proved that treatment did make a lot of differences on the third grade experimental group' performance on the post-test. Thus, it can be concluded that consciousness raising tasks are effective learning tools that can be used in the language classroom to make learners aware of form where explicit instruction is necessary.

This study also suggested that implementing CR activities would help learners to improve their knowledge of grammar. This study showed that the students were more active in class while they were learning the grammar point because they were asked to extract the grammar point themselves by focusing on the examples in their handout through working collaboratively. Applying this approach may train learners in techniques which they can then use to study independently. In practice, grammar consciousness raising tasks deemphasize the overwhelming role of the teacher which is the case with traditional approaches and in return permeate a fascinating discovery view for learning and teaching grammar.

The findings of this study are in line with the findings of previous studies by Ellis $(1994,1997 a, 2002)$, Fotos (1993, 1994) and Schmidt $(1990,1993)$, who have all investigated the merits of promoting learners' consciousness of grammatical forms. Moreover, in accordance with Fotos (1993), communicative exposure to grammar structures presented through formal instruction tended to strengthen and increase the learners' accuracy and the results of the present study support this observation. Results of the study imply that learners were eager to do C-R tasks because these tasks constituted a kind of puzzle which when solved enabled learners to discover how a linguistic feature works. The results are also consistent with Ellis's (2003) observation that "what learners find out for themselves while solving a grammar problem is better remembered than what they are simply told" (p. 163), which in turn provided some empirical support for the use of inductive C-R tasks for grammar instruction.

Breaking down the C-R tasks in this study into several steps may help students decide whether they have learned the grammar point or not. Moreover it may strengthen their learning and put less cognitive burden on learners in comparison to traditional approaches. The idea of setting a manageable language focus for each teaching step in CRT is consistent with the skill-building theories (Ellis, 2003) which claim that learners learn the grammar of a language first by developing its declarative knowledge through intensive teaching activities focusing on separate constituents broken down from the whole grammar system before they can proceduralize such knowledge and turn it into a form available for automatic use in communicative situations.

The findings of the present study are in tune with Fotos $(1993)$ and Schmidt $(1990,1993)$ studies who underscored the central role for conscious mental operations in learning and argued that learners need to notice the features of input for them to turn into intake. As the learners work in group in the case of CRT, it can be suggested that consciousness raising tasks allow the learners to become familiar with group work and task performance. 
In addition to contextualization in CRT, another feature that may have made the example sentences more useful to the learners was the highlighting of those sentences in the texts so as to facilitate their identification.

The learners in this study performed the tasks in L1 and L2. Possibly, this has induced the learners, especially the less proficient ones, to benefit more from performing of the tasks ( Nassaji \& Fotos, 2011). It is worth noting that since CR tasks are based on discovery-learning, using L1 may help the learners make the most of their prior knowledge to discover and understand the rules more effectively. This suggests that possibly in an EFL setting like Iran and especially in noncommunicative classrooms where the focus is on grammar, the CR tasks are likely to result in better gains if performed in the students' L1.

In accordance with Nassaji's (2000) suggestion that one learner in each group should be more proficient than the other members to help the less proficient ones to understand and discover the rules more successfully, for each group, one of the more proficient students was chosen as the head. This more proficient student was asked to help the rest of the group understand and discover the grammatical rules. Therefore, this also might have been a cause for CR groups more effective maintenance of grammatical rules.

One of the activities which made the present study a little different from some previous studies (Fotos, 199; Fotos \& Ellis, 1991) was the addition of feedback by the teacher. It must be noted that while performing the tasks in groups, whenever the students faced a problem, they raised their hands and asked for help and subsequently feedback was provided to help solve their problem. This finding provides support for Fotos \& Ellis' (1991) suggestion that providing the learners with feedback may enhance the effectiveness of CR tasks. Such feedback may ensure learners' mastery of a particular stage of discovery before they moved onto the next stage, which in turn may have contributed to their perceiving the whole learning and teaching process being more systematically organized, moreover allowing the teacher to better monitor individual informants' learning progress. The peer feedback which is evident in CRT may serve to provide valuable opportunities for the particular informant and his group members to scaffold each other's understanding of the targeted grammar items.

\section{Conclusions and Implications}

This study has presented evidences regarding the effectiveness of grammar consciousness-raising tasks in promoting learners' grammatical knowledge of the targeted structures to significant levels. Grammar consciousness-raising tasks may be suggested as useful pedagogy at a time when many educators are looking for acceptable activities to have formal grammar instruction in their communicative classrooms, and other teachers are probing for communicative activities which harmonize with the aims of more conventional educational curricula focusing on the formal study of language components. Consciousness raising as a general pedagogic device can be used very broadly to different areas of language teaching. Moreover, inductive C-R approach characterized by guided discovery of rules before their presentation may involve greater depth of processing than is the case with traditional deductive approaches. Specifically, as has been observed in this study, allowing the informants to use L1 seemed to have promoted their deeper engagement with the communicative tasks, as those learners may otherwise remain quiet during the collaborative work stages. Contextualization and increasing salience by means of visual highlighting consciousness raising tasks could be applicable to or advisable for those who adopt other inductive approaches to teaching $\mathrm{L} 2$ grammar. The inductive C-R tasks might increase the interest level of learning grammar because of the cognitive challenges or simply the novelty they brought forth to the learning process.

Regardless of the approach to be effectuated, there are different learner types: some prefer learning and applying rules, while others are happier with a more deep-end approach. Therefore, learners' attitudes, motivation, needs, cognitive orientation, differences, as well as context of the learning situation should be taken into account in educational settings. It is advisable for teachers to investigate, at different degrees of depth, the effects of adopting different methodological approaches for teaching their grammar syllabi to their own learners, so that they can be better informed while making pedagogic decisions related to grammar teaching. This, certainly, is not an easy task, as it needs not only planning, but also full understanding of course purposes and learners' affective domain. Possibly, an eclecticism involving an integration of C-R and other pedagogic approaches may be more desirable way to handle this particular component of the language that is grammar at the classroom context.

Hence, the findings of this research put forward the following implications for EFL teachers and learners, syllabus designers, and test developers: grammar instruction through CRT implies the integration of a higher order thinking skills such as discovery process into the language classroom ; CRT can provide opportunity for teachers to integrate grammar and other language items /skills; implementing CRT provides opportunity for learner-centered classroom; CRT can foster learner autonomy in learning. 


\section{References}

Alexander, L. G. (1990). Longman English grammar practicefor intermediate students. New York: Addison wesely Longman Limited.

Ansarin, A. A. \& Arasteh, B. (2012). Effectiveness of consciousness-raising in acquisition of English dative alternation. Vigo International Journal of Applied Linguistics( VIAL)(9), 9-38.

Baleghizadeh, S. (2012). Grammatical syllabus and EFL textbooks:the need for consciousness-raising activities . Per Linguam , 28(1), 11-116.

Bankier, B. (2010). onsciousness-raising activities: What they are and why you should be using them.

Bardovi-Harling, K. \& Comajoan, L. (2008). Order of acquisition and developmental readiness. In B. Spolsky, \& M. F. Hult (Eds.), The handbook of educational linguistics (pp. 384-397). Malden: Blackwell Publishing Ltd.

Celce-Murcia, M., Dörnyei, Z., \& Thurrell, S. (1997). Direct approaches in L2 instruction: A turning point in communicative language teaching? TESOL Quarterly, 31(1), 141-152.

Colina, A. A. \& Mayo, M. D. P. G. (2007). Attention to form across collaborative tasks by low-proficiency learners in an EFL setting. In M. d. Mayo (Ed.), Investigating tasks in formal language learning (pp. 91-116). Multilingual Matters Ltd.

Dekeyser, R. M. (2009). Cognative psychological processes in second language learning. In M. H. Long, \& C. Doughty (Eds.), The hand book of language teaching (pp. 119-138). Malden: Blackwell Publishing Ltd.

Ellis, R. (1992). Second language acquisition and language pedagogy. Bristol: Multilingual Matters.

Ellis, R. (1993, spring). The structural syllabus and second language acquisition. TESOL QUARTERLY, 27(1), 91-113.

Ellis, R. (1994). The study of second language acqusition. Oxford: Oxford University Press.

Ellis, R. (1997a). Becoming Grammatical. Retrieved from Impact grammar: http://www.impactseries.com/grammar/becoming.html

Ellis, R. (2002). Grammar teaching - practice or consciouness-raising? In J. C. Richards, \& W. A. Renandya (Eds.), Methodology in language teaching (pp. 167-174). New Yourk: Cambridge University Press.

Ellis, R. (2003). Task-based language learning and teaching. New York: Oxford Univesity.

Ellis, R. (2005a). principles of instructed language learning. System, 209-224.

Ellis, R. (2005b). Instructed language learning and task-based teaching. In E. Hinkel (Ed.), Handbook of research in second language teaching and learning (pp. 713-728). New Jersey: Lawrence Erlbaum Associates,inc.

Ellis, R. (2006, March). Current issues in the teaching of grammar:An SLA prespective. TESOL Quarterly, 86-107.

Ellis, R. (2009a). Implicit and explicit Learning, knowlege and instruction. In R. Ellis, S. Loewen, C. Elder, R. Erlam, J. Philp, \& H. Reinders, Implicit and explicit knowledge in second language learning, testing and teaching (pp. 3-25). Multilingual Matters.

Flower,W.S. \& Coe, N. . (1976). Nelson English Language Tests. London : Butler and Tanner Ltd.

Fotos, S. \& Ellis, R. (1991). Communicative about grammar:A task based approach . TESOL Quarterly, 25(4), 605-628.

Fotos, S. (1993). Consciousness raising through focus on form:Grammar task performance versus formal instruction. Applied linguistics, 14(4), 385-407.

Fotos, S. (1994). Integrating grammar instruction and communicative language use through grammar consciousness-raising tasks. TESOL Quarterly, 28(2), 323-351.

Hulstijn, J. H. (2005). Theoretical and empirical issues in the study of implicit and explicit second-language learning. SSLA, 129-140.

Jalali, M. (2012). Consciousness-raising and noticing: A study of EFL learners' grammar test performance. Iranian EFL Journal, 8(6), 159-180.

Kojima, H. (2004). Grammar instruction in the learner-centered EFL classroom. 101-109.

Krashen, S. D. (1981). Second language acquisition and second language learning. California: Pergamon Press Inc.

Krashen, S. D. (1982). Principles and practice in second language acquisition. Pergamon Press Inc.

Mohamed, N. (2004 , July). Consciousness-raising tasks: A learner perspective. ELT, 58(3), 228-237.

Naeini, J. (2008). Error correction an indication of consciousness-raising. Novitas Royal, 2(2), 120-137.

Nassaji, H \& Fotos, S. (2004). Current developments in research on the teaching of grammar. Annual Review of Applied Linguistics, 24, 126-145.

Nassaji, H. \& Fotos, S. (2011). Teaching grammar in second language classrooms:Integrating form-focused instruction in communicative context. New York: Routledge.

Nassaji, H. (2000). Towards integrating form-focused instruction and communicative interaction in the second language classrooms: Some pedagogical possibilities. The Modern Language Journal, 241-250.

Nettle, M. \& Hopkins, D. (2003). Developing grammar in context. Cambridge: Cambridge University Press.

Nitta, R.\& Gardner, S. (2005, January). Consciousness-raising and practice in ELT coursebooks. ELT, 59(1), 3-13.

Osuka, N., \& Yamamoto, A. (2005). Grammar teaching using form-focused tasks. JALT, 647-657.

Rachmawati. (2011, September). Consciousness raising as an alternative approach to teaching grammar. Jurnal Penelitian Dan Pemikiran Pendidikan, 1, 82-90.

Richards, J. C. \& Rodgers, T. S. (2001). Approaches and methods in language teaching (Second Edition ed.). Cambridge: Cambridge University Press.

Rodríguez, A. G. (2009, April). Teaching grammar to adult English language learners: focus on form. 4. Washington: CAELA Network.

Sarhady, T. (2011). The impact of consciousness-raising on learning gramar: Interval between teaching and practice or not? Modern Journal of Language Teaching Methods (MJLTM) , 1(3), 24-38.

Schmidt, R. (1990). The role of consciousness in second language learning. Applied Linguistics, 11(2), 129-158. 
Schmidt, R. (1993). Awareness and second language acquisition. Annual Review Of Applied Linguistics, 206-226.

Schmidt, R. (1995). Consciousness and foreign language learning : A tutorial on the role of attention and awareness in learning.

Shokouhi, A. H. (2009, Winter). Consciousness-raising tasks versus deductive approach: Two form-focused instruction types in teaching grammar to iranian high school EFL learners. Journal of Education, 4(4), 51-70.

Tavakoli, H. (2012). A dictionary of language acquisition. Tehran: Rahnama Press.

Willis, D. \& Willis, J. (1996). Consciousness-raising activities. Retrieved from www.willis-elt.co.uk/documents/7c-r.doc

Willis, J. (1996). A framework for task-based learning. Harlow: Addison Wesley Longman Limited.

\section{Appendix A}

\section{Task (Preposition of Time)}

1. Underline the time expression in this passage.

I made an appointment to see Mr. Bean at 3 o'clock on Tuesday $11^{\text {th }}$ February to discuss my application for a job. Unfortunately, he was involved in a car accident in the morning and rang to cancel the appointment. I made another appointment to see him at 10 o'clock on Friday 21 $1^{\text {st }}$ February. However, when I got to his office, his secretory told me that his wife had died at 2 o'clock in the night and that he was not coming into the office that day.

She suggested I rescheduled for some time in March. So I made a third appointment to Mr. Bean at 1 o'clock on Monday 10th March. This time I actually got to see him. However, he informed me that they had now filled all the vacancies and suggested I contact him again in 1988. I assured him that he would not be seeing me in either this or the next century.

2. Write the time phrases into this table.

\begin{tabular}{|l|l|l|}
\hline At & In & On \\
\hline 3 o'clock & & \\
\hline & & \\
\hline & & \\
\hline & & \\
\hline & & \\
\hline
\end{tabular}

3. Make up rule to explain when to use "at", "in" and "on" in time expression. (Ellis, 2003, p. 18) 